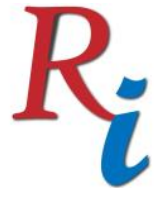

Asia Proceedings of Social Sciences

(APSS)

www.readersinsight.net/APSS

\title{
The Flexural and Compressive Strength of Recycled Concrete
}

\section{Nouf Alsabbagh}

Civil Engineering Department, Kuwait University Kuwait

*Corrosponding author's Email: nouf.sabbagh@ku.edu.kw

Peer-review under responsibility of $4^{\text {th }}$ Asia International Conference 2018 editorial board (http://www.utm.my/asia/our-team/) (C) 2018 Published by Readers Insight Publisher, lat 306 Savoy Residencia, Block 3 F11/1,44000 Islamabad. Pakistan, info@readersinsight.net This is an open access article under the CC BY-NC-ND license (http://creativecommons.org/licenses/by-nc-nd/4.0/). 


\section{Research High Iight s}

This study designed an experimental program to test the effect of substituting virgin coarse aggregates with recycled aggregates obtained from demolished concrete. Four different concrete mixes were designed at a strength of $30 \mathrm{MPa}$, with different partial replacement percentages. Samples were cast from each mix and tested for the flexural strength as well as the compressive strength. Results were compared to a control mix and the density and workability were also examined. Results showed that in spite of the slight effect noted on both flexural and compressive strength, good quality concrete can still be achieved. The use of aggregates in a saturated surface dry condition was also recommended, in order to achieve better results.

\section{Research Objectives}

Limitations in natural resources have drawn the necessity to develop sustainable solutions for the future of the concrete industry. The use of recycled concrete as a replacement for virgin coarse aggregates, does not only help conserve natural resources, but it also significantly reduces the amounts of construction and demolition wastes sent to landfills. It also helps contribute in solving the problem of scarcity of land available for landfills, in small countries such as Kuwait (Celdex, 1999). Recycling enhances the world's advancement towards a better environment. This study supports recycling through demonstrating the ability of recycled aggregates to compete with virgin ones, in terms of technical specifications, and thus compete with them in the market (Hester \& Harrison, 1995).

\section{Methodology}

This study started with the design of three different concrete mixes at a strength of $30 \mathrm{MPa}$. All mix constituents were kept constant, except for the coarse aggregate content sized 3/4" and $3 / 8$ ". Each mix substituted virgin aggregates with recycled pieces of concrete, at different 


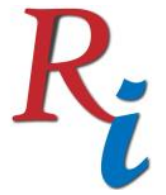

\section{Asia Proceedings of Social Sciences \\ (APSS) \\ www.readersinsight.net/APSS}

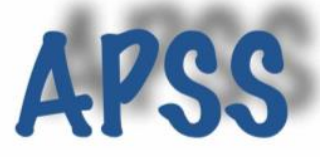

percentages. The first mix utilized $100 \%$ replacement, whereas the other two utilized $50 \%$ and $0 \%$ replacement, making the latter one the control mix.

The workability of each concrete mix was tested through the Slump Test (C143M-15a, 2015). Observations on the slump values drew the necessity to alter the experimental design to include yet another fourth mix to act as another control mix. This fourth mix also utilized a $0 \%$ replacement rate, but with a controlled slump.

Cubes were cast at a dimension of $100 \mathrm{~mm}$, from all four concrete mixes. These cubes were tested for the compressive strength, at the ages of 7 and 28 days. Beams were also cast from each of the four mixes, at a dimension of $100 \mathrm{~mm}$ in width, $100 \mathrm{~mm}$ in height and $500 \mathrm{~mm}$ in length. These beams were tested for their flexural strength at the age of 28 days (C78M-18, 1994). Comparison of all results achieved was analyzed using ANOVA 1 software.

\section{Results}

At the age of 7 days, the compressive strength of the mixes that utilized a replacement of $50 \%$ and $0 \%$ were found to be 30 and $30.5 \mathrm{MPa}$ respectively. These two mixes showed similarity at a 5\% level of significance (Alsabbagh, 2002). The average compressive strength of the mix that utilized $100 \%$ replacement, was found to be $35 \mathrm{MPa}$. The recycled aggregates absorbed part of the mixing water which lowered the water cement ratio and resulted in this increase (Neville, 1995). All mixes were statistically different from each other.

At the age of 28 days, all mixes surpassed the minimum design compressive strength of $30 \mathrm{MPa}$. The average compressive strength of the mix at $100 \%$ replacement, was found to be the lowest at a value of $37 \mathrm{MPa}$. This value differed statistically at a 5\% level of significance from all the others. The compressive strength of the mixes at a replacement of $50 \%$ and $0 \%$ were found to be 40.5 and 41.5 MPa respectively (Alsabbagh, 2002).

The flexural strength of all mixes, tested at the age of 28 days, were found to be similar at a $5 \%$ level of significance. All Moduli of Rupture were within the acceptance range of the ACI Code 318. 


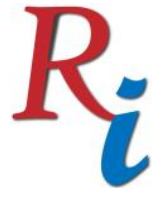

\section{Asia Proceedings of Social Sciences \\ (APSS) \\ www.readersinsight.net/APSS}

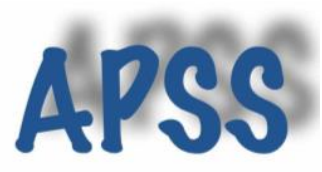

\section{Findings}

The Flexural Strength of Recycled Aggregate Concrete was not affected by the introduction of recycled aggregates. Recycled Aggregate Concrete was able to reach the design strength at the age of 28 days. The workability of the mix was lowered by the introduction of recycled aggregates, due to the aggregates tendency to absorb water from the mix. It is recommended to use recycled aggregates in the state of saturated surface dry condition (SSD) to achieve better results. It is also recommended to apply long-term tests over a long period of time to detect time dependent volume changes (Alsabbagh, 2002).

\section{Acknowledgement}

The research was supported by the Civil Engineering Department at Kuwait University. Appreciation is forwarded to the Kuwait Foundation for the Advancement of Sciences (KFAS) for their cooperation and financial support.

\section{References}

Alsabbagh, N. (2002). Utilization of Recycled Aggregates in Concrete Mixes. (Master of Science in Civil Engineering), Kuwait University, Kuwait.

C78M-18, A. C. (1994). Standard Test Method for Flexural Strength of Concrete (Using Simple Beam with Third-Point Loading). In. West Conshohocken, PA: ASTM International.

C143M-15a, A. C. (2015). Standard Test Method for Slump of Hydraulic-Cement Concrete. In. West Conshohocken, PA: ASTM International.

Celdex, S. a. (1999). Proposal for Kuwait Municipality. Retrieved from Kuwait:

Hester, R. E., \& Harrison, R. M. (1995). Waste treatment and disposal: Royal Society of Chemistry.

Neville, A. M. (1995). Properties of Concrete. Harlow, NY: Pearson. 